UDC $502-630: 64$

(C) 2017

\title{
Forest and forest ecosystems in the structure of lands of forestry-based industrial assignment
}

\author{
O. Furdychko,
}

Academician of the NAAS, Doctor of Economics, Doctor of Agricultural Sciences

O. Drebot,

Corresponding Member of the National Academy of Sciences of Ukraine, Doctor of Economics

A. Bobko,

Candidate of Agricultural Sciences

Institute of Agroecology and Nature Management, National Academy of Sciences of Ukraine

The purpose. To assess terms which are used in forestry and in registration of land resources, their conformity to European measurements. Methods. Analysis and comparison with European standards. Results. They studied the term "forest" using different sources of its explanation beginning from V.I. Dal's time, state standards of USSR, Wood Code of Ukraine, EEC/FAO of the United Nations (2000). Conclusions. Necessity is proved of modernizing the specified term which should attaches it the sense of wood ecological system by its components.

Key words: definition, ecosystem, land, content, forest, explanation, term.

The practice of Ukrainian forestry and forest management is several centuries, starting with the simplest of taxing individual plots of forest and forest cottages, completing forest stands and generalizing forest records within individual entities of the administrative-territorial division of the country and the country as a whole. This level of forestry in Ukraine has reached the end of the second half of the twentieth century. In addition, unfortunately, with the content of "use of forests", instead of "the use of land forests for the cultivation of forests". Sectorial terms and definitions, which were the found to be the used in the sectorial and national vocabulary and national culture, were systematically processed. Among them, such as forest farming, forestry, forestry production, forest, etc. The term "Forest ecosystem" is not included in the official handbook of the State Statistics Service of Ukraine "Environment of Ukraine".

Nevertheless, the task of forestry "growing of forest" is blurred by a number of insignificant uses of "forest resources", bypassing "the cultivation and sale of wood in a state of growth" to obtain forest income and the constant rejuvenation and improvement of forest plantations. Only in the beginning of the XXI century, in the Ukrainian discourse, the aspect of "getting the most profit (income) from land use should be the priority condition for the provision of land to forestry entities", in the middle of the nineteenth century. It was known that "the task of a felony is the same as a horticulturist and a farmer: to sow and grow plants" [1].

The UN ECE /FAO "Forest Resources Assessment" also does not emphasize forest ecosystems, with more emphasis on forest resources with regard to the allocation of forests to categories of wood harvesting for the production of forest materials [2]. Scientific proposals in the periodical press forestry recognize "as a type of economic activity ... forestry, and forestry enterprises - land users", are not heard [3]. The same applies to the proposition that "Accounting and monitoring of forest ecosystems ... are required, but they are not covered at all by reporting and scientific information" [4]. So:

Research topic. Forest and forest ecosystems within the limits of the land plots granted for the implementation of forestry (LPIF).

The aim of the study. Estimation of the terms used in the field of forestry, their compliance with the content of agro-ecological forestry and modernization on the example of the state forestry entity to intensify forestry production and growing of forest - the main products of the sectorial. 
Method of research. Analysis of terms and tax rates used in forestry and forest management, their compliance with land use categories, established by national land use classification standards, and UN ECE/FAO Standard Statistical Classification of Land Use.

Object of study. Land, forestry and FL as an object of labor and rational formation of forest ecosystems, taking into account the demand for forest materials of business and trade.

The result of the study. There is a significant inconsistency in the definition of the term "Forest", also derivative words from it, with the terms in European law. As an example, according to C. Oliver, "today forests occupy about 30\% of the land of the planet Earth - from the tropics to high latitudes" [5]. This definition is somewhat generalized, impersonal, without reference to the use of land. The necessity of their coordination is the proposed, including on the introduction of forest inventory for components of forest ecosystems. This will allow systematizing the accounting and reporting of land users about the use of the category "Forest Land" at the present level.

\section{Terms and definitions}

Let us pay attention, from us beforehand to the public editions and normative acts of the late twentieth century. At the same time, we note that most of the legal acts, accounting, design and reporting materials of that time were the published in Russian. Therefore, we will translate the current vocabulary into the Ukrainian language. Let us start with the basic concepts of "Forest", "Forest farming", "Forestry" and others. The most important is the term "Forest", from which many derivatives of terms come from, the use of which, in the end, affects the economic results of land use and the formation of forest ecosystems (Table 1).

Table 1. Definition of the term "Forest" during evolutionary development of the forestry in Ukraine

\begin{tabular}{|c|c|c|}
\hline Source & Description & Remark \\
\hline V.I. Dal & $\begin{array}{l}\text { Space covered with growing and growing trees: it is a } \\
\text { forest at the root: cut and cleaned of knots and tops } \\
\text { (from a coma) of wood, logs: wood in a log house. }\end{array}$ & $\begin{array}{l}\text { Description of the term } \\
\text { for the forest as wood } \\
\text { in a state of growth } \\
\text { and after felling }\end{array}$ \\
\hline $\begin{array}{l}\text { GOST } 18486-87 . \\
\text { Forestry. Terms and } \\
\text { definitions }\end{array}$ & $\begin{array}{l}\text { Element of the geographical landscape, consisting of a } \\
\text { set of dominant trees, shrubs, grass cover, animals and } \\
\text { microorganisms, which in their development are } \\
\text { biologically interconnected, affect each other and the } \\
\text { external environment. }\end{array}$ & $\begin{array}{l}\text { Without defining the } \\
\text { object of labor and } \\
\text { production of the main } \\
\text { products. }\end{array}$ \\
\hline $\begin{array}{ll}\text { Forest Code of } \\
\text { Ukraine }\end{array}$ & $\begin{array}{l}\text { Forest is a type of natural complexes, which combines } \\
\text { mostly woody and shrub vegetation with appropriate } \\
\text { soils, herbal vegetation, animal world, microorganisms } \\
\text { and other natural components }\end{array}$ & $\begin{array}{l}\text { Modern forests in } \\
\text { Ukraine are objects of } \\
\text { anthropogenic origin, if } \\
\text { we talk about forest } \\
\text { ecosystems. }\end{array}$ \\
\hline $\begin{array}{l}\text { UN. Economic } \\
\text { Commission for } \\
\text { Europe/FAO [2] }\end{array}$ & $\begin{array}{l}\text { Land with tree crown cover (or equivalent stocking level) } \\
\text { of more than } 10 \text { percent and area of more than } 0.5 \text { ha. } \\
\text { The trees should be able to reach a minimum height of } 5 \\
\mathrm{~m} \text { at maturity in situ. May the consist either of the closed } \\
\text { forest formations where trees of various stores and } \\
\text { undergrowth cover a high proportion of the ground; or of } \\
\text { open forest formations with a continuous vegetation cover } \\
\text { in which tree crown cover exceeds } 10 \text { percent. } \\
\text { Young natural stands and all plantations, provided for } \\
\text { forestry, which have yet to reach a crown density of } 10 \\
\text { percent or tree height of } 5 \mathrm{~m} \text {, are included under forest, as } \\
\text { are areas normally forming part of the forest area which } \\
\text { are temporarily untucked because of human intervention }\end{array}$ & $\begin{array}{l}\text { The definition has a } \\
\text { modern content on the } \\
\text { state of land use in the } \\
\text { field of forestry, } \\
\text { including the } \\
\text { components of forest } \\
\text { ecosystems, although } \\
\text { it is not the } \\
\text { emphasized that the } \\
\text { forest in modern } \\
\text { interpretation is a } \\
\text { forest ecosystem that } \\
\text { is and is formed during }\end{array}$ \\
\hline
\end{tabular}




\begin{tabular}{|l|l|l|}
\hline & $\begin{array}{l}\text { or natural causes but which are the expected to revert to } \\
\text { forest. } \\
\text { Includes: Forest nurseries and seed plantations, which } \\
\text { are an integral part of the forest; } \\
\text { Forest roads, cleared paths, fire protection structures } \\
\text { and other small open areas in the forest; } \\
\text { in national parks, nature reserves and other protected } \\
\text { areas, such as special ecological, scientific, historical, } \\
\text { cultural or spiritual interests; } \\
\text { Wind turbine and protective strips of trees over 0.5 } \\
\text { hectares and more than } 20 \mathrm{~m} \text { wide. } \\
\text { Excludes: lands that area predominantly used for } \\
\text { agricultural practices. }\end{array}$ \\
\hline
\end{tabular}

After all, since the beginning of the emergence of forestry, as a branch of plant growing, the object of labor becomes land, land. This is the reflected in the definition of the term VI Dahl: "Space covered by growing and growing trees." For until that time the general survey, the subjects of agriculture, was not yet completed. "Space" had not yet properly set boundaries. The definition of the term "Forest", according to the standard of the Soviet era, defines it as an "Element of the Geographic Landscape", without specifying at the same time either the objects of labor or its main products.

The European Forestry Institute also conducted a study of the term "Forest" in 21 countries, including Austria, Germany, Poland, Russia and France. It is the proved that it does not have a single definition. Everyone has some differences [6].

The Forestry Code of Ukraine establishes a slightly different definition: "Forest is a type of natural complexes, which combines mainly woody and shrub vegetation with appropriate soils, herbal vegetation, animal world ..." [7]. After all the most important thing is terms "Forest" supposedly represents a "type of natural complexes", rather than biocenosis of tree species, whose cultivation is intended for the extraction of wood (of forest).

\section{The term "Forest" as defined by the UN ECE/FAO (2000)}

The table in his definition acquires the practical category "Forest land" (Forest the land) with all its components, and not only subcategories "Lands covered with forest vegetation". In essence, it contains a description of the components of the forest ecosystem and the main ultimate goal of land use is the growing of forest (wood).

Decode the term "forest lands = forest ecosystems" according to their components, which are given above in the translation from English into Ukrainian (Table 2). It allows to systematize the accounting and reporting, bringing them to European standards in Ukraine and in other countries of the World.

\section{Forest as an ecosystem and its components}

\begin{tabular}{|c|l|l|}
\hline $\mathrm{N}$ & \multicolumn{1}{|c|}{ Components } & Name Reduced \\
\hline 1 & $\begin{array}{l}\text { Plots with cover of wood crowns more than 10 percent and an area of } \\
\text { more than 0.5 hectares. Age-maturing mature trees reach a height of at } \\
\text { least } 5 \text { meters: the lands covered with forest vegetation natural lands of } \\
\text { HDL natural. }\end{array}$ & $\begin{array}{l}\text { Lands covered FV } \\
\text { natural. }\end{array}$ \\
\hline 2 & $\begin{array}{l}\text { Young plantings and all plantations created for forestry, which have not } \\
\text { yet reached the 10 per cent crown density, or the height of a tree of 5 } \\
\text { meters: Lands covered with forest vegetation artificial. }\end{array}$ & $\begin{array}{l}\text { Lands covered FV } \\
\text { artificial. }\end{array}$ \\
\hline 3 & $\begin{array}{l}\text { Plots that form part of the forest system and temporarily not occupied by } \\
\text { forest vegetation as of result of human intervention or natural } \\
\text { phenomena. The land temporarily not covered by forest vegetation. }\end{array}$ & $\begin{array}{l}\text { Lands is temporarily } \\
\text { not covered FV. }\end{array}$ \\
\hline
\end{tabular}




\begin{tabular}{|c|l|l|}
\hline 4 & $\begin{array}{l}\text { Forest nurseries and seed plantations, which are an integral part of the } \\
\text { forest: Forest nurseries, plantations. }\end{array}$ & $\begin{array}{l}\text { Lands is under } \\
\text { nurseries, } \\
\text { plantations. }\end{array}$ \\
\hline 5 & $\begin{array}{l}\text { Forest roads, cleared paths, fire protection structures and other small open } \\
\text { areas in the forest under service and technical objects. }\end{array}$ & Lands STO. \\
\hline
\end{tabular}

It should be the noted that adaptation, in practice, does not require new expenditures of the state budget. The current working documents of the forest management, of course, must be the brought into line with the above division. Bringing the data of reporting and accounting past years is easy to reform to the accounting of land use for forest ecosystems (Fig. 1 - 2). Appropriate adaptation requires only experience and education in the field of forestry, as well as diligence in work.

The given diagrams refer to the most important in the field of forestry - the division of land use categories "Land of forests - forests" into components of forest ecosystems. One of the most important taxation indicators is observed - the total area of forests (forest ecosystems) for the period from 1988 [8] to 2011 [9] does not decrease (calculated on basis of indicated sources). Even increased by 373.4 thousand hectares. The main thing here is that the main components of the forest ecosystem "Lands CFV" from forests of natural origin are the moved to forests artificial creation.
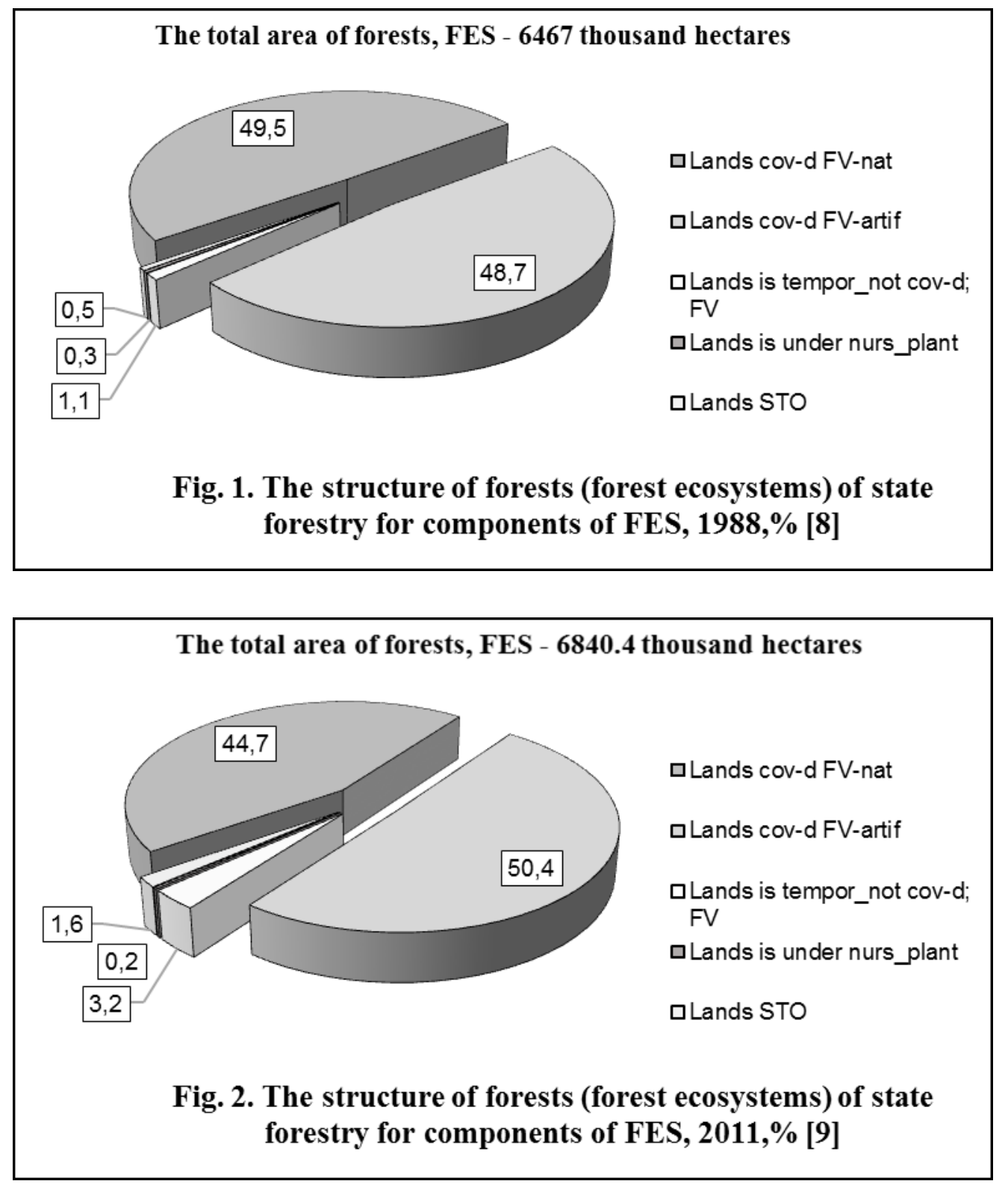
It should also be the noted that in the distribution of forest the land and forest ecosystems the norms of European forestry, including the attribution of woodland to covered lands with forest vegetation, are taken into account. The same applies to the subcategories of land use "not closed crowns of Forest Cultures", which are logically and justified to attribute to the component "Lands CFV - artificial". We do not concern land use in national parks, nature reserves and other protected areas, because these land users should be subject to a unified system of taxation and the formation of land use categories. In addition, it should always be borne in mind that the assessment of the state of the land in the presence / absence of biocenosis is one scope of observations; another area is their accounting for the intended purpose.

\section{Conclusions}

Recognizing the truly logical definition of the term "Forest" in the system of European experience, Ukrainian science and practice should ensure its implementation. Then, speaking about term "forests" in the sense of forest ecosystems, it will be clear that this is not just about the component of "Lands covered with forest vegetation", but also about others (Table 2). The theory and practice of the Ukrainian forestry have reached level for the wide introduction of the updated content of the terms and definitions. Regarding of description of use forest land for the forest ecosystems, taking into account the categories, established by the UN ECE/FAO Standard Statistical Classification of Land Use, developed by the Statistical Commission and the European Commission at the conference of European statisticians in 1989 [10].

Taking into account the above, as well as the implementation of the Land Code of Ukraine (Article 57, paragraph 2), it is necessary to draw up the Law of Ukraine "The Procedure for the Use of the land is provided for forestry ", providing for rational and tested principles of the Polish Law (Ustawa) about forests (1991). It would also be desirable if ECE / FAO UN developed the International Standard for Key Indicators of Forest Ecosystem Taxation and the establishment of regional monitoring for its organized and large-scale implementation, ongoing monitoring and public information on the state of forests / forest ecosystems and their environmental impact.

\section{Bibliography}

1. Furdychko O.I. Environmental problems of nature management in science and practice of forestry production / O.I. Furdychko // Bulletin of the National Academy of Sciences of Ukraine. - K., 2012 - No. 4. - P. $40-41$.

2. Forest resources of Europe, CIS, North America, Australia, Japan and New Zealand. Main Report // United Nations. Economic Commission for Europe. Food and Agriculture Organization of the United Nations. - New York and Geneva, 2000. - p. 62 - 67.

3. Bobko A. N. The forestry economy begins with the use of designated land / A. N. Bobko // Zh. Economy of Ukraine. - 2014 - \# 5. - P. 90.

4. Furdychko O.I. Forest lands as an object of labor and ecological observation in forestry / O.I. Furdychko, AM Bobko // Bulletin of Agrarian Science. Scientific and Theoretical Journal of the National Academy of Agrarian Sciences of Ukraine. 2013, No. 7. - P.60 - 64.

5. Oliver C. Global forest bioresources: Present challenges and opportunities / C. Oliver // Abstracts of the 115th Anniversary International Scientific Conference "Earth bioresources and environmental biosafety: Challenges and opportunities, Kyiv, 4-7 November 2013. - Kyiv: National university of life and environmental sciences of Ukraine/ 2013. - P. 50.

6. Compilation of Forestry Terms and Definitions /Andreas Schuck, Risto Paivinen, Tumo Hytonen, and Brita Pajari // European Forest Institute. Internal Report \# 6, 2002.

7. Forest Code of Ukraine. Law, Code of 21.01.1994 No. 3852-XII in the wording of 10.03 .2017 // Bulletin of the Verkhovna Rada of Ukraine (VVR), 1994, No. 17, p. 99.

8. Brief reference book on the forest fund of the Ukrainian SSR on January 1, $1988 / /$ Ministry of Forestry of the USSR. Chipboard - K., 1989. - $119 \mathrm{p}$. 
9. Directory of Forest Fund of Ukraine on the materials of state registration of forests as of 01.01.2011 // State Agency of Forest Resources of Ukraine. Ukrainian state the project forestry production the enterprise.- Irpin, 2012.-130 p.

10. UN ECE. Standard Statistical Classification of Land Use // Statistical Commission and European Economic Commission. Conference of European Statisticians. Thirty-seventh plenary session. - Geneva, June 12-16, 1989. 